\title{
Yläkoulun oppilaiden ja opettajien käsityksiä verkkokiusaamisesta vuorovaikutusilmiönä
}

\author{
Niina Huhtala \& Sanna Herkama
}

\section{Tiivistelmä}

Kuten kasvokkaisessa myös teknologiavälitteisessä vuorovaikutuksessa voi ilmetä kiusaamista. Patchinin ja Hindujan $(2006,152)$ mukaan teknologiavälitteinen kiusaaminen (engl. cyberbullying) tarkoittaa tarkoituksellista ja toistuvaa toisen ihmisen vahingoittamista median tai elektronisen tekstin välityksellä. Tällaista kiusaamista voi tapahtua kännykän, internetin tai näiden molempien välityksellä (Kowalski, Limber \& Agatston 2008; Campbell 2005). Tämän $\operatorname{artikkelin}^{1}$ tavoitteena on tarkastella sitä, millainen vuorovaikutusilmiö verkkokiusaaminen on oppilaiden ja opettajien käsityksissä. Artikkelin toisena tavoitteena on tarkastella oppilaiden ja opettajien käsityksiä ilmiön vakavuudesta sekä tuoda esiin näiden käsitysten yhtäläisyyksiä ja eroja.

Artikkeli pohjaa kuuteen täsmäryhmähaastatteluun, joihin osallistui yhteensä 12 oppilasta ja 10 opettajaa yläkouluista. Tutkimuksen tulokset kuvaavat sitä, millaisena vuorovaikutusilmiönä verkkokiusaaminen ymmärretään. Haastatteluaineiston sisällönanalyysi osoitti, että verkkokiusaamiseen liitetään lukuisia viestinnällisiä muotoja. Muodot jäsenneltiin viiteen eri ryhmään sen mukaan, mihin niillä haastateltavien mukaan pyrittiin. Näitä tavoitteita olivat 1) kiusatun maineeseen ja statukseen vaikuttaminen, 2) kiusatun itsearvostukseen ja itsetuntoon vaikuttaminen, 3) kiusatun eristäminen vuorovaikutuksesta, 4) pelon aiheuttaminen sekä 5) kiusatun omaisuuden vahingoittaminen. Jäsennys ei ainoastaan erottele kiusaamisen viestinnällisiä muotoja, vaan se tarjoaa näkökulman verkkokiusaamisen tavoitteellisuuden ja kiusaamisen vaikutusten tarkasteluun. Lisäksi tulokset osoittavat, että oppilaiden ja opettajien käsitykset verkkokiusaamisen vakavuudesta poikkeavat toisistaan.

Asiasanat: internet, kiusaaminen, verkkokiusaaminen, oppilaat, opettajat, vuorovaikutus

${ }^{1}$ Artikkeli perustuu Niina Huhtalan pro gradu -tutkielmaan, jonka ohjaajana on toiminut Sanna Herkama Helsingin yliopistosta. 


\section{Johdanto}

Viime vuosina teknologiavälitteinen vuorovaikutus on lisääntynyt merkittävästi lasten ja nuorten vertaissuhteissa. Nykyään yhä useammalla lapsella ja nuorella on käytössään älypuhelin, jossa yhdistyvät internetin ja kännykän ominaisuudet. Uudet viestintäteknologiat ovat mahdollistaneet monimuotoisia kiusaamisen välineitä ja kanavia. Kiusaamista voi tapahtua kännykän, internetin tai näiden molempien välityksellä (Kowalski, Limber \& Agatston 2008; Campbell 2005). Verkkokiusaaminen on ajankohtainen aihe, joka on saanut osakseen paljon mediahuomiota. Se on herättänyt vanhempien ja opettajien keskuudessa paljon huolta.

Verkkokiusaamisen tutkimus on yleistynyt vuoden 2005 jälkeen. Ilmiöstä on tehty lähinnä kuvailevia tutkimuksia kvantitatiivisin menetelmin kartoittaen ilmiön yleisyyttä (Li 2007), kiusaamisen kanavia ja muotoja (Li 2007; Patchin \& Hinduja 2006; Slonje \& Smith 2008) sekä sen suhdetta perinteiseen kiusaamiseen (Li 2007). Myös verkkokiusaamisen välittömät seuraukset ja puolustautumiskeinot sekä huoltajien tietoisuus ilmiöstä ovat olleet mielenkiinnon kohteena (Dehue, Bolman \& Völlink 2008; Patchin \& Hinduja 2006; Slonje \& Smith 2008). Ilmiötä on tarkasteltu myös aggressiivisuuden näkökulmasta (Ybarra \& Mitchell 2004). Joissakin tutkimuksissa ilmiötä on lähestytty kvalitatiivisesti. Tällöin tavoitteena on ollut esimerkiksi ilmiön olemuksen selkeyttäminen (Vandebosch \& Van Cleemput 2008) sekä kiusaamisen motiivien tarkastelu (Varjas ym. 2010).

Verkkokiusaamista on aiemmin tutkittu valtaosin kartoittavasta ja kuvailevasta näkökulmasta. Tällainen tutkimus on tarjonnut tietoa ilmiön yleisyydestä sekä siitä, miten ja missä verkkokiusaamista tapahtuu. Aiemmat tutkimukset eivät kuitenkaan ole tarjonneet ymmärrystä verkkokiusaamisesta vuorovaikutusilmiönä. Tässä artikkelissa tarkastelemme opettajien ja oppilaiden käsityksiä verkkokiusaamiseen liittyvästä viestinnästä sekä viestinnän tavoitteista, erityispiirteistä ja vakavuudesta.

\section{Verkkokiusaaminen ja sen yleisyys}

Suomessa ei ole vakiintunutta käsitettä teknologiavälitteiselle kiusaamiselle. Ilmiöstä on kirjoitettu ainakin sähköisen kiusaamisen, mobiilikiusaamisen, verkkokiusaamisen, nettikiusaamisen, elektronisen kiusaamisen ja jopa "saippauksen" nimissä (Hamarus 2008, 71). Käytämme tässä artikkelissa käsitettä verkkokiusaaminen, jonka katsomme pitävän sisällään niin puhelimen kuin internetinkin kautta tapahtuvan kiusaamisen.

Aikaisemman tutkimuskirjallisuuden pohjalta ei myöskään muodostu yhtenäistä kuvaa verkkokiusaamisen määritelmästä (Nieminen \& Pörhölä 2011). Kirjallisuudessa kuitenkin nostetaan esiin useita perinteiselle kiusaamiselle tyypillisiä ominaispiirteitä, kuten kiusaamisen toistuvuus ja pitkäkestoisuus sekä 
vallan epätasapainoinen jakautuminen kiusaajan ja kiusatun välisessä vuorovaikutussuhteessa. Patchin ja Hinduja $(2006,152)$ määrittelevät verkkokiusaamisen tietoiseksi ja toistuvaksi toisen ihmisen vahingoittamiseksi median tai elektronisen tekstin välityksellä. Smith ym. (2008, 376) lisäävät määritelmään aggressiivisuuden vaatimuksen ja voimasuhteiden epätasapainon. Heidän mukaansa kiusaamista on yksilön tai ryhmän aggressiivinen ja tahallinen, elektronisen kontaktin välityksellä tapahtuva viestintä, joka kohdistuu toistuvasti puolustuskyvyttömään yksilöön. Vandeboschin ja Van Cleemputin (2008) mukaan on kyse verkkokiusaamisesta, mikäli 1) joku pyrkii tahallaan satuttamaan toista ja toinen kokee itsensä satutetuksi, 2) kyseessä on toistuva ja pitkäkestoinen prosessi ja 3) osapuolten välillä vallitsee voimasuhteiden epätasapaino, joka voi syntyä esimerkiksi kiusaajan anonyymiydestä tai paremmista tietoteknisistä taidoista.

Aikaisemmat tutkimukset ja kartoitukset osoittavat, että noin viisi prosenttia suomalaisista lapsista ja nuorista on kokenut verkkokiusaamista (EU Kids Online II 2010; Sourander ym. 2010). Vuoden 2010 pääkaupunkiseudun kouluterveyskyselyn mukaan kiusaamista tapahtuu yhä enemmän internetin ja kännykän välityksellä (Lommi ym. 2010, 48). Joka kymmenes yläluokkalainen oli kohdannut verkkokiusaamista viimeisen vuoden aikana. Toisaalta esimerkiksi Salmivallin ja Pöyhösen (2012) vajaa 18000 vastajaa käsittäneessä tutkimuksessa verkkokiusaamisen kohteeksi oli joutunut kaksi prosenttia ja toisia oli kiusannut verkossa prosentti 8-15-vuotiaista oppilaista. Kiusaamiseksi katsottiin tapaukset, joissa kiusaamista oli tapahtunut vähintään 2-3 kertaa kuukaudessa.

\section{Verkkokiusaamisen muodot ja erityispiirteet}

Verkkokiusaaminen voidaan jaotella kännykkä- ja internetkiusaamiseen. Kännykkäkiusaaminen tarkoittaa esimerkiksi pilasoittoja tai ikävien tekstiviestien lähettämistä kiusatulle. Myös kuvien tai videoiden ottaminen kamerakännykällä ja niiden luvaton levittäminen voi olla yksi osa kännykkäkiusaamista (Smith ym. 2006, 1). Internetkiusaamista tapahtuu esimerkiksi internetin sosiaalisissa ympäristöissä, kuten sosiaalisen median yhteisöissä, kuvagallerioissa, chateissa ja vuorovaikutteisissa peliympäristöissä tai sähköpostin ja pikaviestinohjelmien välityksellä (Vandebosch \& Van Cleemput 2008).

Kowalski, Limber ja Agatston (2008, 47-51; ks. myös Campbell 2005; Willard 2005) jaottelevat verkkokiusaamisen muotoja, jollaisina he pitävät esimerkiksi vihamielistä kommentointia, häirintää, mustamaalaamista, toisena esiintymistä, juonittelua, eristämistä ja nettivainoa. Vihamielistä kommentointia (engl. flaming) tapahtuu esimerkiksi keskustelupalstoilla tai chateissa. Ominaista kommentoinnille on, että yllättävät vihamieliset viestit aiheuttavat voimasuhteiden epätasapainoa osapuolten väliseen vuorovaikutussuhteeseen. Usein kiusattu alkaa itsekin vastavuoroisesti lähettää häntä kiusannutta henkilöä koskevia 
loukkaavia viestejä. Toinen verkkokiusaamisen muoto on häirintä (engl. harassment) (Kowalski, Limber \& Agatston 2008, 47). Häirintä on toistuvaa uhkaavien, häiritsevien tai loukkaavien viestien lähettämistä valitulle henkilölle, joka ei itse osallistu viestintään vastavuoroisesti.

Kolmas aikaisemmissa tutkimuksissa tunnistettu verkkokiusaamisen muoto on mustamaalaaminen (engl. denigration). Kiusatusta levitetään halventavia ja loukkaavia juoruja websivustoilla tai niitä lähetetään ketjukirjeen muodossa eteenpäin sähköpostitse tai pikaviestinohjelman välityksellä. Tällaisiin tarinoihin saatetaan liittää mukaan kiusatun kuva, jolloin loukkaava viesti henkilöityy kiusattuun entistä vahvemmin. (Kowalski, Limber \& Agatston 2008, 48.) Toisena esiintyminen (engl. impersonation) on neljäs verkkokiusaamisen muodoista. Kiusaaja saattaa käyttää internetissä kiusatun henkilöllisyyttä tuottaen tällä tavoin harmia kiusatun ihmissuhteille. Kiusatun nimimerkin takaa kiusaaja lähettää negatiivisia, halventavia tai vihjailevia viestejä kiusatun tuttaville, jolloin tämän maine ja ihmissuhteet vaarantuvat. (Kowalski, Limber \& Agatston 2008, 48; Willard 2005.)

Juonittelu (engl. trickery) viittaa luottamuksen väärinkäyttöön. Tämä voi tarkoittaa esimerkiksi kiusatun henkilökohtaiseksi tarkoittaman sähköpostin lähettämistä eteenpäin ulkopuolisille osapuolille. Eristämistä (engl. exclusion) puolestaan tapahtuu esimerkiksi pikaviestinohjelmissa tai kuvagallerioissa siten, että kiusattu torjutaan tietoisesti kaverilistoilta tai jätetään kiusatun kommentit täysin huomiotta. (Kowalski, Limber \& Agatston 2008, 49-50; Willard 2005.) Nettivaino (engl. cyberstalking) on hyvin lähellä häirinnän käsitettä. Nettivaino kuitenkin eroaa häirinnästä siten, että kiusattuun kohdistuvat viestit sisältävät enemmän uhkailua, joka saa kiusatun tuntemaan terveytensä tai jopa henkensä olevan vaarassa. (Kowalski, Limber \& Agatston 2008, 50.)

Aikaisemmissa tutkimuksissa on nostettu esiin verkkokiusaamisen erityispiirteitä (Kowalski, Limber \& Agatston 2008; Nieminen \& Pörhölä 2011; Patchin \& Hinduja 2006; Varjas ym. 2010; Ybarra \& Mitchell 2004). Tällaisia ovat esimerkiksi 1) verkkokiusaamisen kasvottomuus eli anonyymius, 2) nonverbaalisten vihjeiden puute, 3) viestien julkisuus, 4) valvonnan puute sekä 5) laaja tavoitettavuus.

Tutkimuksissa yleisimmin mainittu verkkokiusaamisen erityispiirre on kasvottomuus eli anonymiteetti (Kowalski, Limber \& Agatston 2008, 64; Ybarra \& Mitchell 2004, 332; Patchin \& Hinduja 2006, 154; Varjas ym. 2010). Kasvottomuus vapauttaa kiusaajan normatiivisista ja sosiaalisista rajoitteista. Tämän vuoksi myös sellaiset ihmiset saattavat alkaa kiusata, jotka eivät muuten sitä tekisi. (Pörhölä \& Kinney 2010, 82; Varjas ym. 2010.) Anonymiteetti voi johtaa myös siihen, että kiusaaja voi viedä tekonsa teknologiavälitteisesti viestiessään kasvokkaisia tilanteita pidemmälle (Kowalski, Limber \& Agatston 2008, 64; Patchin \& Hinduja 2006, 154). Lisäksi kiinnijäämisen riski voidaan kokea pieneksi (Pörhölä \& Kinney 2010, 86). 
Nonverbaalisten vihjeiden puuttuminen liittyy vahvasti kasvottomuuteen. Kasvokkain viestittäessä vuorovaikutuksen osapuolet voivat tehdä tulkintoja toistensa asenteista ja tunteista nonverbaalisten vihjeiden perusteella. Teknologiavälitteisestä vuorovaikutuksesta nonverbaalisten eleiden myötä tällaiset tunneilmaukset puuttuvat. Tällöin väärinkäsitysten riski on suurempi ja kiusaajakin voi tehdä herkemmin ylilyöntejä, koska hän ei näe kohteensa välittömiä reaktioita. (Kowalski, Limber \& Agatston 2008, 66.)

Viestien julkisuus on eräs verkkokiusaamisen erityispiirre. Suuret yleisöt saattavat kannustaa huomionhakuisia kiusaajia ylilyönteihin. (Oksanen \& Näre 2006, 117-118.) Kun perinteisessä koulukiusaamisessa yleisönä ovat korkeintaan koulun oppilaat, voi internetissä ladatun videon katsoa rajaton määrä ihmisiä. Pörhölä ja Kinney (2010) toteavat, että pienessä yhteisössä alkanut kiusaamisilmiö voi laajentua julkiseksi ilmiöksi ja näin vaikuttaa kiusattuun merkittävästi. Julkinen nolaaminen on heidän mukaansa tehokas tapa satuttaa ja loukata ihmistä.

Neljäs perinteistä ja verkkokiusaamista erottava tekijä on valvonnan puute. Yleensä kiusaaminen tapahtuu internetissä aikuisten valvonnan ulkopuolella. Internetin sosiaalisissa yhteisöissä on jonkin verran valvontaa, mutta siinä usein tukeudutaan nuorten omiin ilmiantoihin. Valvonta ei myöskään ylety henkilökohtaisiin sähköposteihin tai pikaviestinohjelmiin. (Patchin \& Hinduja 2006, 154; Campbell 2005, 4.) Lapset ja nuoret myös käyttävät yhä useammin tietokonetta omassa huoneessaan tai internetiä älypuhelimellaan (Aarnio \& Multisilta 2012). Tällöin vanhemman on entistä vaikeampi valvoa lapsensa internetin käyttöä tai havaita tämän osallisuutta kiusaamisprosessiin (Patchin \& Hinduja 2006, 154).

Laaja tavoitettavuus tarkoittaa sitä, että verkkokiusaaminen ei rajoitu mihinkään tiettyyn aikaan päivästä tai tiettyyn ympäristöön. Kiusattu on tavoitettavissa miltei koko ajan, koska lähes jokaisella suomalaisella koululaisella on nykyään käytössään puhelin ja mahdollisuus internetin käyttöön. (Oksanen \& Näre 2006, 10.) Laaja tavoitettavuus tarkoittaa toisaalta myös sitä, että kuka tahansa voi joutua verkkokiusaamisen kohteeksi. Vaikka joissakin tutkimuksissa (Slonje \& Smith 2008), kartoituksissa (Mustonen \& Peura 2007) ja opinnäytetöissä (Huhtala 2007) on käynyt ilmi, että kiusattu ja kiusaaja saattavat olla ennestään tuttuja, on tapauksia, joissa kiusattu ei tiedä, kuka häntä kiusaa. Esimerkiksi Slonjen ja Smithin (2008) tutkimuksessa 33 \% kiusatuista ei tuntenut kiusaajaansa.

\section{Tutkimuksen tavoite ja menetelmät}

\section{Tutkimustehtävä}

Tämän artikkelin tavoitteena on syventää näkemystä verkkokiusaamisesta vuorovaikutusilmiönä. Tavoitteeseen pyrimme tarkastelemalla yläkouluikäisten oppi- 
laiden ja heidän opettajien käsityksiä ilmiöstä. Kiinnostuksen kohteina ovat tutkittavien käsitykset ilmiöön liittyvästä viestinnästä sekä viestinnän tavoitteista, erityispiirteistä ja vakavuudesta. Tutkimuksessa selvitetämme myös, millaisia yhtäläisyyksiä ja eroja on oppilaiden ja heidän opettajiensa verkkokiusaamista ja sen vakavuutta koskevissa käsityksissä.

\section{Tutkimusaineisto ja sen analysointi}

Tutkimusaineisto koostuu kolmesta opettajien ja kolmesta oppilaiden täsmäryhmähaastattelusta. Ryhmähaastattelun etuna on se, että yksilölliset eroavaisuudet ja subjektiivisen tuntemukset suodattuvat pois ja tutkijalla on mahdollisuus kuulla niitä hahmottamistapoja ja käsitteitä, joiden puitteissa ryhmä toimii ja ajattelee kulttuurisena ryhmänä (Alasuutari 2007, 150). Niemisen ja Pörhölän $(2011,83)$ mukaan verkkokiusaaminen on arka tutkimusaihe, minkä vuoksi he näkevät ryhmähaastatteluiden sopivan aiheen tutkimiseen.

Toteutetut haastattelut olivat teemahaastatteluja. Teemahaastattelu etenee ennakkoon asetettujen teemojen varassa mutta keskustelussa on liikkumavaraa uusille teemoille, jotka mahdollisesti nousevat aiheen kannalta merkityksellisiksi (Hirsjärvi \& Hurme 2001, 63; Hirsjärvi, Remes \& Sajavaara 2006, 197). Tutkimuksen ryhmähaastatteluihin osallistui 12 yläkouluikäistä oppilasta pääkaupunkiseudulta kahdesta eri koulusta ja 10 opettajaa kolmesta eri koulusta. Oppilaat osallistuivat haastatteluihin luokka-asteittain. Oppilashaastattelujen sukupuolijakauma oli melko tasainen. Tutkimukseen osallistuneista opettajista enemmistö oli naisia. Haastatteluihin osallistuminen oli vapaaehtoista ja luottamuksellista. Haastateltavilta ei kysytty sitä, olivatko he itse kokeneet kiusaamista tai olleet kiusaajina, eikä oppilaiden haastatteluissa ilmennyt viittauksia tällaisiin kokemuksiin. Kaksi opettajaa kertoi oma-aloitteisesti olleensa kouluaikoinaan koulukiusattuja. Tätä ei kuitenkaan otettu analyysissä huomioon, koska vastaavaa tietoa ei ollut käytössä muiden osallistujien osalta. Aineiston keräämisen ja analysoinnin suoritti ensimmäinen kirjoittaja.

Huolimatta siitä, että verkkokiusaamista voidaan pitää arkana tutkimusaiheena, olivat keskustelut vilkkaita. Erityisesti oppilaiden täsmäryhmähaastatteluissa kiinnitettiin huomiota siihen, etteivät oppilaat kokisi tilannetta epämiellyttäväksi. Haastattelija pidättäytyi tietoisesti kysymästä oppilailta kokemuksista vaan pikemminkin pyysi heitä kuvaamaan omia käsityksiään tai pohtimaan kuvitteellisia tilanteita. Tästä huolimatta moni oppilas halusi jakaa omakohtaisia havaintojaan verkkokiusaamisesta, mitä voidaan pitää osoituksena luottamuksellisuudesta. Saatu haastatteluaineisto sisälsi oppilaiden ja opettajien käsityksiä ja kokemuksia verkkokiusaamisesta, sen vakavuudesta sekä vaikutuksista.

Haastattelut tuottivat yhteensä noin kuusi tuntia nauhoitettua aineistoa. Haastatteluaineisto litteroitiin tekstimuotoon (noin 90 sivua). Analysoinnissa noudatettiin teoriasidonnaista sisällönanalyysiä (Tuomi \& Sarajärvi 2002). Aluksi aineisto järjestettiin ja pelkistettiin ATLAS.ti 6 analyysiohjelmistolla. 
Haastatteluissa mainitut kiusaamisviestinnän muodot (nimittely, haukkuminen, juoruilu, uhkailu jne.) listattiin ja kvantifioitiin. Tämän jälkeen aineistossa esiintyneet kiusaamiseen muodot ryhmiteltiin erilaisiksi mallityypeiksi. Eskolan ja Suorannan $(1998,181)$ mukaan mallityypit tiivistävät ja tyypillistävät. Kyseinen analyysivaihe tuotti kuvauksen verkkokiusaamisen eri muodoista.

Verkkokiusaamisen muotojen tarkastelu ei kuitenkaan tarjonnut kovin syvällistä ymmärrystä verkkokiusaamiseen liittyvästä viestinnästä, joten analyysia jatkettiin pohtimalla sitä, mihin kiusaamiseen liittyvällä viestinnällä haastateltavien mukaan pyrittiin. Tämän jäsentelyn tuloksena syntyivät haastateltavien kuvaamat verkkoviestinnän viisi tavoitetta ja niihin liittyvät kiusaamisen muodot. Lisäksi analyysissä kiinnitettiin huomiota siihen, miten vakavana opettajat ja oppilaat pitivät verkkokiusaamista sekä millaisia eroja ja yhtäläisyyksiä oppilaiden ja opettajien verkkokiusaamisen vakavuutta koskevissa käsityksissä oli.

\section{Verkkokiusaamisen muodot ja tavoitteet}

Haastateltavat kuvasivat runsaasti sitä, millainen vuorovaikutusilmiö verkkokiusaaminen heidän mielestään on. Verkkokiusaamisen muodot voitiin analyysin perusteella jäsennellä viiteen eri ryhmään, jotka kuvaavat haastateltavien näkemyksiä verkkoviestinnän tavoitteista. Nämä tavoitteet ovat 1) kiusatun maineeseen ja statukseen vaikuttaminen, 2) kiusatun itsearvostukseen ja itsetuntoon vaikuttaminen, 3) kiusatun eristäminen, 4) omaisuuden vahingoittaminen sekä 5) pelon aiheuttaminen. Jokainen haastateltavien mainitsema verkkokiusaamisen yksittäinen muoto, kuten nimittely ja juonittelu, sijoitettiin jäsennyksessä jonkin tavoitteen alle (ks. Kuvio 1).

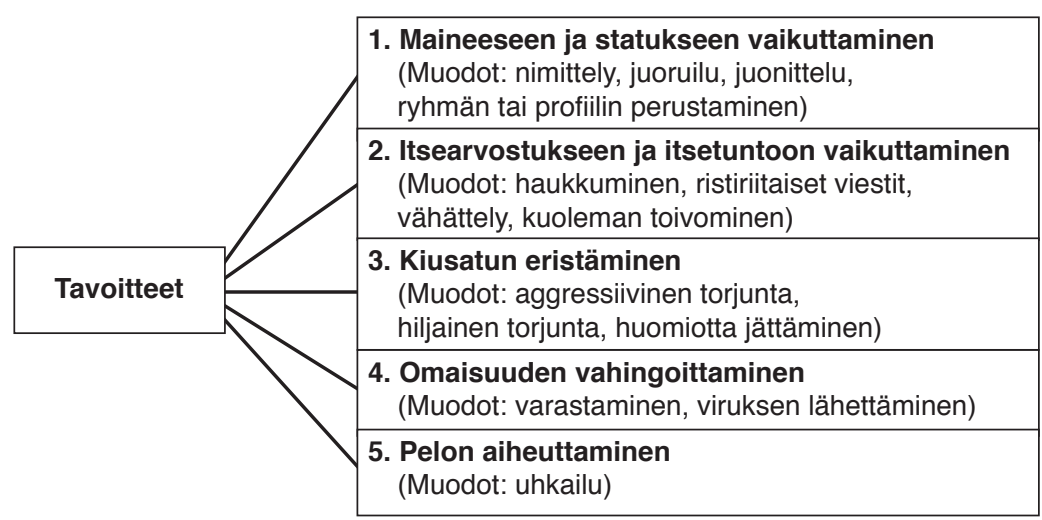

KUVIO 1. Oppilaiden kuvaamat verkkokiusaamisen tavoitteet ja niihin liittyvät kiusaamisen muodot. 


\section{Kiusatun maineeseen ja statukseen vaikuttaminen}

Kiusatun maineeseen ja statukseen kielteisesti vaikuttaminen oli yksi tutkimuksessa havaittu verkkokiusaamisen tavoite. Haastateltavat kuvasivat kiusatun maineeseen vaikuttamisen olevan tyypillistä erityisesti tyttöjen keskuudessa, mutta myös haastateluihin osallistuneet pojat toivat esiin julkisen nolaamisen yhtenä verkkokiusaamisen muotona. Haastateltavien mukaan tällaisen viestinnän tavoitteena oli levittää kielteistä kuvaa kiusatusta ja saada muut toimimaan tämän käsityksen mukaisesti. Viestinnän seurauksena kiusatun ympärillä olevat ihmiset alkoivat suhtautua kiusattuun kielteisesti, kuten opettajan 1/2 esimerkki osoitti:

\section{"Halutaan hämmentää sitä soppaa, ja ehkä jotenki sellasta, että kaikki näkee, kaikki muutki alkais nyt, kun mä kirjoitan sen seinälle. Siinä- hän yhellä klikkauksella tästä koulusta kolmesataa saattaa nähä sen kirjotuksen, että kaikki muutki olis sitä vastaan.” (Ope 1/2)}

Haastateltavien mainitsemista kiusaamisen muodoista nimittely, juorujen levittely, juonittelu, ryhmän tai profilin perustaminen sekä kuvien ja videoiden levitys olivat sellaisia kiusaamisen muotoja, joiden voitiin nähdä vaikuttavan kiusatun maineeseen kielteisesti. Nimittely tarkoittaa kiusatun ihmisen kutsumista erilaisilla loukkaavilla nimityksillä. Nämä nimitykset saattoivat haastateltavien mukaan liittyä esimerkiksi seksuaaliseen suuntautumiseen, olemukseen tai luonteeseen. Nimitys antoi joidenkin haastateltavien mukaan vihjeen siitä, miksi kiusaaminen oli alkanut. Esimerkiksi nimitys "Hiiri" saattoi erään haastateltavan mukaan viitata kiusatun ujoon ja alistuvaan olemukseen. Nimittelyn käsitettiin tapahtuvan yleensä sosiaalisissa yhteisöpalveluissa tai kuvagallerioissa, jolloin nimitys henkilöityi vahvemmin kiusattuun, hänen kuvaansa ja henkilökohtaisiin tietoihinsa. Nimitys ei välttämättä vastannut kiusatun omaa käsitystä itsestään, kuten seuraavasta aineisto-otteesta ilmeni:

"Nimittely on se, mitä mä oon kuullut, et kutsutaan joksikin tai nimitellään joksinkin, josta itte ei pidetä tai ei ainakaan mielletä sitä... että sehän on ristiriitasta sun oman mielikuvan ja jonku muun kertoman välillä.” (Ope 3/3)

Opettajan 3/3 kommentti osoitti, että nimittelyllä ei välttämättä ole tekemistä havaittavissa olevien ominaisuuksien kanssa, vaan kyse on pikemminkin kiusaajan tai kiusaajajoukon muodostamista mielipiteistä ja käsityksistä, jotka jalostuvat ja leviävät vuorovaikutuksessa. Erityisesti oppilaat toivat esiin kiusaamisen pitkittymisen ja laajenemisen. Kuvausten mukaan kiusaaminen saattoi

${ }^{2}$ Kunkin sitaatin jälkeen on merkitty, onko kyseinen ote oppilaiden vai opettajien täsmäryhmähaastattelusta. Numero 1/2 kertoo, että kyseinen opettaja on ensimmäinen osallistuja toisesta täsmäryhmästä. 
alkaa harmittomasta vitsailusta tai kaverusten välisestä riidasta, josta se levisi vertaisryhmään.

Juorujen levittelyä kuvailtiin haastatteluissa useaan otteeseen. Juoruilu on kielteisten, kiusattuun henkilöityvien tietojen levittämistä. Tiedoissa ei välttämättä ollut haastateltavien mukaan todellisuuspohjaa, vaan ne saattoivat olla yksittäisten kiusaajien tai ryhmien muodostamia tarinoita, joita levitettiin laajalle yleisölle, kuten opettaja 2/2 kuvaili:

"Sillä tavalla et ne laittaa juoruja kiertämään jostaki ja levittää jotaki juttuu, mikä ei välttämättä ole totta...et joku on tehny jotaki vaikkei oiskaan tehny, ollu vaikka jonku pojan kans.” (Ope 2/2)

Juoruilun katsottiin olevan helppo keino vaikuttaa käsityksiin kiusatusta, koska juorut usein henkilöityivät kiusattuun ja hänen tekemisiinsä. Haastateltavien mukaan kiusatun on lähes mahdotonta puolustautua tai vaikuttaa hänestä liikkuviin juttuihin sen jälkeen, kun juoru on lähtenyt liikkeelle.

Haastateltavien mukaan kiusattu ei kykene vaikuttamaan maineeseen, jonka juorut hänelle luovat. Puolustautumisen vaikeuden ajateltiin johtuvan ennen kaikkea viestien nopeasta leviämisestä ja laajasta yleisöstä. Tämä tukee vahvasti esimerkiksi Hamaruksen (2008) toteamusta siitä, että juorut vetävät ryhmää syvemmälle kiusaamisprosessiin ja ylläpitävät kiusatun matalaa statusta. Samalla hänen mukaansa muun ryhmän koheesio lisääntyy.

Joskus juoru voi olla lähtöisin juonittelusta. Haastateltavien kuvauksissa juonittelu tarkoitti sellaisten salaisuuksien tai tietojen, jotka kiusaamisen kohde on aiemmin luottamuksella kertonut, levittelyä tai hyödyntämistä kiusaamiseen. Juonittelua oli haastateltavien mukaan myös kiusatun tunnusten ja salasanojen varastaminen tai se, että kiusaaja on saanut kiusatun tunnukset ja salasanat haltuunsa käyttäen hyväksi kiusatun miellyttämishalua sekä hyväksytyksi tulemisen tarvetta. Opettajien mukaan ei ole harvinaista, että nuori antaa itse tunnuksensa toiselle. Nuori haluaa tulla hyväksytyksi omassa vertaisryhmässään ja tekee sitä, minkä ajattelee edistävän vertaisryhmään kiinnittymisessä tai ystävien saamisessa. Rainivaaran ja Karhusen (2006) mukaan loukkaaminen vaatii jossain määrin tietoa toisesta ihmisestä. Täten loukkaaminen heidän mukaansa saattaa edellyttää vastavuoroista itsestä kertomista tai aktiivista tiedonhankintaa. Myös tässä aineistossa mainittiin aktiivinen tiedonhankinta. Tytön $2 / 3$ kuvauksen mukaan jostakin kiusaamistapauksesta kuuleminen voi saada oppilaan kiinnostumaan asiasta ja hankkimaan lisätietoa tapauksesta. Tiedonhankinnan seurauksena kiusatusta voi hänen mukaansa muodostua kielteinen kuva ja tämä saattaa haastateltavan mukaan johtaa siihen, että henkilö liittyy kiusaamiseen.

"Jos siit (kiusatusta) kuulee jotain juttua, vaikka se ei oliskaan tuttu, niin alat tyyliin hankkimaan jotain tietoa siit tyypistä ja sit aattelet, 
että tuo onkin kauhea ja alat kiusata sitä... vaikka se ei oikeasti olekaan." (Tyttö 2/3)

Haastateltavat kuvasivat myös kiusatun tunnusten väärinkäyttöä yhtenä verkkokiusaamisen keinona. Haastateltavien mukaan toisen tunnuksia voi hyväksikäyttää lähettämällä kiusatun nimissä kielteisiä tai vihjailevia viestejä tämän tuttaville. Tämä vastaa Kowalskin, Limberin ja Agatstonin (2008) kuvausta toisena esiintymisestä (impersonation): kiusaaja käyttää kiusatun henkilöllisyyttä tuottaen harmia tämän ihmissuhteille tai maineelle. Myös kiusatun yhteisöpalvelun tilille kirjautuminen voi haastateltavien mukaan mahdollistaa kiusatun maineen tahraamisen, kuten seuraavat esimerkit osoittavat:

"Tai sit sä varastat sen käyttäjätunnuksen ja meet kirjoittamaan sinne seinälle, vaik niinku mä oon homo tai tämmöistä.” (Poika 2/2)

"Se (kiusattu) oli ollut siellä kirjautuneena ja sit joku toinen oppilas on mennyt sinne ja lisäilly sinne jotain tyhmiä kommentteja ja liittänyt sinne jotain hölmöjä videoita, että tavallaan... heh heh tää kattoo tällasia videoita täällä YouTubessa.” (Ope 1/3)

Pojan 2/2 kuvaamassa tilanteessa kiusaaja onnistui luomaan vaikutelman, jossa kiusattu henkilö itse tunnustautuu homoseksuaaliksi. Opettajan 1/3 esimerkissä puolestaan syntyi vaikutelma, että kiusattu itse katsoisi noloja videoita internetissä. Haastateltavien mukaan kiusatun on vaikea puolustautua tämän tyyppistä kiusaamista vastaan, koska toisten silmiin yhteisöpalvelun profiilin statuspäivitykset, kuvat ja videot näyttäytyvät hänen omina tuotoksinaan. Omaehtoinen julkinen nolaus mielletään haastateltavien käsityksissä muiden tekemää julkista nolaamista vakavammaksi.

"Sellainen julkinen nolaaminen. Ja ku se periaatteessa olis ite viel tehnyt sen niin se olis vielä kamalampaa. Sitä on vaikea puolustella sitten, että en se ollut mä... se on kuitenkin omasta seinästä.” (Poika $1 / 2)$

Profilin tai ryhmän perustaminen kiusatun nimellä on yksi keino vaikuttaa kiusatun maineeseen. Aineistosta löytyi muutamia kuvauksia profiilin perustamisesta yhteisöpalveluun kiusatun nimellä ja kuvalla. Sosiaalisissa yhteisöpalveluissa on mahdollista perustaa profiili henkilölle, bändille, julkkikselle tai yritykselle suhteellisen vapaasti. Tätä mahdollisuutta voidaan haastateltavien mukaan hyödyntää myös kiusaamiseen. Kiusatun on erittäin vaikea puolustautua, koska hän ei itse omista profiilin käyttäjätunnuksia ja salasanoja. Toisinaan kiusattu ei itse edes tiedä profiilin olemassaolosta: 
"Oli perustettu toisen nimellä profiili, jossa sitten haukuttiin kyseistä henkilöä hänen tietämättään." (Ope 1/3)

Opettajan 1/3 kuvauksessa kiusaaminen tapahtui täysin kiusatun selän takana. Kiusattu oli loukkaavan viestinnän kohteena, mutta viestintä oli suunnattu muille ihmisille. Tällaisissa tilanteissa voidaan olettaa, että kiusaajien tavoitteena on nimenomaan kiusatun maineen manipulointi ja toisten asenteisiin vaikuttaminen. Sama opettaja kuvasi myös ironista "ylistysryhmää" seuraavasti:

"Oli perustettu ryhmä... sellainen "ylistämme [kiusatun nimi]" -ryhmä. Se oli niitten sellainen niinku joku palvonnan kohde mut se oli tehty silleen ironisesti." (Ope 1/3)

Kuvien ja videoiden levitys ja manipulointi vaikutti aineiston perusteella olevan verkkokiusaamisen yleisesti tunnettu muoto. Tämä muoto mainittiin jokaisessa haastattelussa. Haastateltavien mukaan kuvien tai videoiden levitys tarkoitti sitä, että kiusatusta otetaan kuva epäedullisessa tilanteessa ja levitetään se internetiin ilman lupaa.

"Otetaan video esimerkiksi jostakin mitä se tekee. Esimerkiksi silloin, ku se on ollut humalassa tai jotain ja laitetaan se YouTubeen." (Poika $1 / 2$ )

Pojan 1/2 kuvaamassa kiusaamistilanteessa valtasuhteiden epätasapaino on suuri. Kiusattu ei välttämättä tiedä kuvan levittämisestä ja jos tietääkin, hän ei pysty sen leviämiseen juurikaan vaikuttamaan. Kuvan manipulointi oli haastateltavien mukaan kyseessä silloin, kun kuvaa muokattiin kiusatun kannalta epäedullisesti. Muokkauksen seurauksena kiusattu saattoi esimerkiksi vaikuttaa kuvassa alastomalta. Haastateltavat mielsivät tämän tyyppisen kiusaamisen erityisen julmaksi siksi, että se voi aiheuttaa kiusatulle pitkäaikaista häpeää. Erityisesti opettajat olivat huolissaan siitä, että kuvat ja videot voivat levitä internetissä hyvin laajalle ja pysyä internetissä vuosienkin ajan.

\section{Kiusatun itsearvostukseen ja itsetuntoon vaikuttaminen}

Toinen haastatteluaineiston pohjalta havaittu verkkokiusaamisen tavoite oli kiusatun itsearvostukseen ja itsetuntoon vaikuttaminen. Tällöin kyse oli esimerkiksi haukkumisesta, vihjailemisesta, vähättelystä ja kuoleman toivomisesta kiusatulle. Kaikissa näissä verkkoviestinnän muodoissa päämääränä oli saada kiusatun itsearvostus horjumaan. Viestit olivat haastateltavien kuvauksissa suoremmin osoitettuja kiusatulle. Kun maineen ja statuksen laskuun vaikuttavan viestinnän kohdeyleisönä oli kiusatun ympärillä oleva yhteisö, itsearvostukseen ja itsetuntoon vaikuttavan viestinnän kohteena on kiusattu itse.

Haukkuminen eli loukkaavien kommenttien osoittaminen kiusatulle, mainittiin haastatteluissa usein. Loukkaukset kohdistuivat haastateltavien mukaan 
tällöin kiusatun ulkonäköön, taitoon, älyyn tai luonteeseen. Joskus loukkaus kohdistui kiusatun perheeseen. Ulkonäköön tai olemukseen kohdistuneen haukkumisen nähtiin tapahtuvan yleisimmin kiusatun kuvan yhteydessä esimerkiksi sosiaalissa yhteisöpalveluissa tai kuvagallerioissa. Taitoon ja älyyn liittyviä loukkaavia kommentteja ajateltiin esiintyvän esimerkiksi peliympäristöissä. Nimittelyn tapaan myös haukkuminen henkilöityi kiusattuun ja hänen ominaisuuksiinsa vahvasti. Haukkuminen kuitenkin erosi haastateltavien kuvauksissa nimittelystä. Kun nimittelyyn kuului olennaisesti erilaisten nimitysten (esim. "Nörtti, "Hiiri” ja "Älykääpiö") käyttö, haukkuminen taas perustui vahvasti kiusatun ominaisuuksien kuvailuun kielteisten adjektiivien avulla (esim. "surkea", "tyhmä", "ruma"). Haastateltavien kuvauksista voidaan tulkita, että olennaista haukkumisessa on pyrkimys toisen loukkaamiseen ja mielipahan aiheuttamiseen sekä siihen, että kiusattu saadaan uskomaan olevansa esimerkiksi rumempi, tyhmempi tai huonompi kuin muut.

Aineistosta löytyi useita kuvauksia ristiriitaisista viesteistä. Tällaista viestintää useat haastateltavat kutsuivat vihjailuksi. Ristiriitaiset viestit olivat haastateltavien mukaan ironisia huomautuksia tai kommentteja, jotka esitettiin näennäisesti harmittomassa muodossa.

"No siis silleen, vihjailla jostain... siis jotain kommentteja, mistä ei kaikki välttämättä tajua, että se on kiusaamista. Voi esim. kommentoida jotain kuvia ivallisesti tai sarkastisesti." (Tyttö 2/3)

Kuten tytön $2 / 3$ kuvauksessa tuli ilmi, ulkopuolisten ihmisten on vaikea tunnistaa kiusaamista näennäisesti viattomista kommenteista, mutta kiusattu henkilö yleensä ymmärtää kiusaajiensa tavoitteen. Viestin sisällön, ilmaisutavan ja kontekstin välinen ristiriita voi saada kiusatun ymmärtämään viestin todellisen tarkoituksen (Karhunen \& Pörhölä 2007). Jokainen uusi viesti tulkitaan kyseisen vuorovaikutussuhteen historian valossa (Rainivaara \& Karhunen 2006, 17). Tarkoituksena onkin loukata tai muistuttaa jostain aiemmasta tapahtumasta, joka on ollut kiusatulle häpeällinen. Tämä on omiaan vaikuttamaan kiusatun itsearvostukseen ja itsetuntoon.

"Joku porukka ja sillä on joku inside-juttu ja siitä muistutetaan silleen, että kukaan muu ei tajua kuin se tyyppi ja ne, jotka on ollut siinä tilanteessa... ja siitä tilanteesta sit muistutetaan." (Tyttö 3/3)

Muutamat haastateltavat kuvasivat vähättelyä. Vähättelyn ajateltiin tapahtuvan esimerkiksi sosiaalissa yhteisöissä statuspäivitysten yhteydessä:

"Just silleen, et kaikkia varmaan kiinnostaa, jos sä oot laittanut jotain." (Tyttö 2/3) 
Vähättelyn ajateltiin kohdistuvan erityisesti kiusatun mielipiteeseen tai kommentteihin ja sillä pyrittiin mielipahan aiheuttamiseen. Lisäksi vähättelyllä tavoiteltiin haastateltavien mukaan sitä, että kiusattu tuntisi omat näkemyksensä merkityksettömiksi. Tämä oli aineistossa hyvin tyypillinen kiusatun itsearvostukseen ja itsetuntoon vaikuttava viestinnän muoto. Useissa haastatteluissa viitattiin myös siihen, että kiusatun tai jonkun hänen lähipiiriinsä kuuluvan toivottiin kuolevan tai käyttäytyvän itsetuhoisesti. Alla olevat esimerkit osoittavat näiden toiveiden olleen erittäin julmia.

"Kommentoi esim. sun pitäis kuolla, et voisit tappaa ittes ja kaikkea tommoista." (Tyttö 1/2)

"Facebookissa toivottu vaikka et jonku äiti kuolee tai siis tällasii tosi niinku julmia juttuja." (Ope 1/2)

Tällaisista kommenteista voisi päätellä, että kiusattu henkilö on menettänyt kiusaajan silmissä ihmisarvonsa, koska hänen toivotaan kuolevan tai riistävän itseltään hengen. Tämä puolestaan viittaisi siihen, että kiusaaminen on jatkunut jo pitkään ja sen myötä käsitykset kiusattua kohtaan ovat muuttuneet entistä kielteisemmäksi. Olweuksen (1992) mukaan kiusaamiseen liittyy ryhmämekanismi, jossa muut ryhmän jäsenet alkavat enenevissä määrin nähdä kiusatun arvottomana ja poikkeavana. Näiden kognitiivisten käsitysten muuttuessa kiusatusta tulee aina vain epäsuositumpi vertaisryhmässä.

\section{Kiusatun eristäminen}

Kolmas aineiston pohjalta tunnistettu verkkokiusaamisen tavoite oli kiusatun eristäminen muusta yhteisöstä tai vuorovaikutuksesta. Eristäminen on tyypillinen kiusaamisen muoto (Lommi ym. 2010; Oliver \& Candappa 2007; Macklem 2003, 2). Kowalskin, Limberin ja Agatstonin $(2008,50)$ mukaan ryhmästä eristäminen internetissä voi tapahtua sanattomasti esimerkiksi torjumalla kiusattu kontakti- ja kaverilistoilta tai sivuuttamalla hänen kommenttinsa täysin. Aineistoon sisältyi muutamia esimerkkejä eristämisestä.

Haastateltavien mukaan kiusattu saatetaan eristää ja torjua yksiselitteisellä aggressiivisella ja torjuvalla kommentilla, jonka viesti on selkeä ja näkyvä. Joskus eristäminen voidaan tehdä hiljaisesti niin, että kaikki muut yhteisön tai ryhmän jäsenet kutsutaan mukaan ryhmään kiusattua lukuunottamatta tai häntä ei hyväksytä ryhmään liittymispyrkimyksistä huolimatta. Torjuminen voi haastateltavien mukaan tapahtua myös niin, että kiusattua henkilöä ei yksinkertaisesti huomioida. Hänen sosiaalisen yhteisön profiilipäivityksiinsä tai muihin avoimesti julkaistuihin kommentteihin ei oteta kantaa:

"No ettei kommentoida koskaan, tai ei nosteta peukkua. Joku jätetään ihan rauhaan." (Ope 2/3) 
Opettajan 2/3 mukaan nuorille on erittäin tärkeää tulla huomioiduksi ja se, että heitä ei huomioida esimerkiksi sosiaalisen median yhteisöpalvelussa, aiheuttaa joillekin oppilaille ahdistusta.

\section{Omaisuuden vahingoittaminen ja pelon aiheuttaminen}

Omaisuuden vahingoittaminen mainittiin haastatteluissa muutamaan otteeseen. Tämä saattoi haastateltavien mukaan tapahtua esimerkiksi ryöstämällä toisen peli-identiteetti ja siihen kuuluvat peliominaisuudet tai pelihahmot, joita toinen oli rahalla hankkinut. Tällaista kiusaamista ajateltiin tapahtuvan erityisesti vuorovaikutteisissa pelimaailmoissa tai nuorempien lasten suosimassa HabboHotelpelissä. Omaisuuden vahingoittamiseen saattoi haastateltavien mukaan liittyä jo aiemmin mainittu juonittelu, jossa kiusattu huijataan luovuttamaan käyttäjätunnukset. Myös haitallisen viruksen lähettäminen mainittiin keinona vahingoittaa kiusatun omaisuutta. Viruksen kaltaiset haittaohjelmat vahingoittavat tietokoneen käyttöympäristöä ja voivat siten tuhota omaisuutta.

Viides tutkimuksessa tunnistettu verkkokiusaamisen tavoite on pelon aiheuttaminen. Uhkailu mainittiin haastatteluissa useaan otteeseen. Uhkailu tarkoittaa pelon ja ahdistuksen aiheuttamista kiusatulle siten, että kiusattu henkilö tuntee terveytensä tai jopa henkensä olevan vaarassa. Uhkailu saattoi haastateltavien kuvauksissa henkilöityä joko kiusattuun itseensä tai hänen lähipiiriinsä. Uhkailussa on kysymys ulkoisen uhan luomisesta eikä niinkään siitä, että kiusatun esimerkiksi toivotaan olevan itsetuhoinen (vrt. aiemmin mainittu verkkokiusaamisen muoto itsetuhoisuus ja kuoleman toivominen). Uhkailun nähtiin aiheuttavan ahdistusta, joka saattoi haastateltavien mukaan ulottua internetin ulkopuolelle tavalliseen elämään. Tämä muistuttaa vahvasti Kowalskin, Limberin ja Agatstonin $(2008,50)$ mainitsemaa nettivainoa.

"Sitä on uhkailtu, että mä tuun tappaa sut ja jotain tuollaista. Jos se lähtee ulos niin se saa pelätä, että joka kulman takana on joku odottamassa et se kävelee siit ohi." (Tyttö 2/1)

Tytön 2/1 esimerkki kuvasi sitä, kuinka uhkailu aiheuttaa pelkoa ja avuttomuuden tunnetta. Uhkailun vakavuutta haastateltavien mukaan lisäsi se, että kiusatun on vaikea suojautua uhkaa vastaan. Suojautumisen ymmärrettiin olevan vaikeaa epätietoisuuden vuoksi. Ensinnäkin kiusattu ei voi tietää, onko uhka todellinen vai ei. Uhkaileeko kiusaaja vain tuottaakseen pelkoa vai onko hän tosissaan uhkaustensa kanssa? Toiseksi, hän ei välttämättä tiedä, kuka häntä uhkailee.

\section{Verkkokiusaaminen on julkisen alueen ilmiö}

Tutkimuksen tulokset osoittavat verkkokiusaaminen olevan ensisijaisesti julkisen alueen ilmiö, koska erityisesti maineeseen ja statukseen liitettyjä kiusaamis- 
viestinnän muotoja kuvailtiin haastatteluissa muita useammin. Tällainen viestintä on julkista ja suunnattu useimmiten kiusatun ympärillä olevalle yhteisölle. Viestinnällä pyritään muodostamaan kiusatusta kielteinen kuva ja yllyttämään toisia liittymään mukaan kiusaamiseen. Tämä tukee aiempien kiusaamistutkimusten huomioita siitä, että kiusaamisprosessissa muiden ihmisten käsitykset muuttuvat asteittain kielteisemmiksi kiusattua kohtaan (Hamarus 2006; Hamarus \& Kaikkonen 2008; Salmivalli 2003).

Kiusatun maineeseen ja statukseen kielteisesti vaikuttavista kiusaamisen muodoista esimerkiksi juoruilun on todettu liittyvän kiusaamisen ryhmämekanismiin, jossa ryhmä alkaa vähitellen uskoa kiusatun olevan muita vähempiarvoisempi. Ryhmä hakee oikeutusta tälle uskomukselle juorun välittämästä tarinasta ja rakentaa kiusatulle stereotypiaa muistuttavan identiteetin. (Hamarus 2006.) Juorut vetävät ryhmää entistä syvemmälle kiusaamisprosessiin, koska ne edesauttavat ryhmässä tapahtuvaa kognitiivista muutosta herättämällä tunteita ja tarjoamalla oikeutuksen kiusaamiselle (Hamarus 2008; Hamarus \& Kaikkonen 2008). Tulosten osoittavat, että kiusatun maineeseen ja statukseen liittyvien kiusaamismuotojen tarkoituksena on saada aikaan jonkinlaisia muutoksia muiden käsityksissä kiusattua kohtaan. Tämän kaltaiseen viestintään liittyy tutkimuksen tulosten perusteella julkisuus sekä vallan epätasainen jakautuminen, mitkä lisäävät loukkaavan viestinnän tehokkuutta. Kiusaamisviestinnän julkisuutta kuvattiin haastatteluissa usein:

"Jos täällä koululla sanoo toiselle, mitä nää nyt käyttää, että joku on vaikka 'huora' niin sitten sen ehkä kuulee kymmenen ihmistä, vaikka sen huutais tos käytävässä. Mut jos sä facebookissa kirjotat sen 'huoran' sinne, niin sen juuriki saattaa kymmenes minuutis vaikka kolmesataa ihmistä nähä. Sä olet nolannu sen, ja kaikkien sellastenki ihmisten silmissä, ketä sä et itte ees tunne. " (Ope 4/1)

Opettajan 4/1 kommentti kuvasi Pörhölän ja Kinneyn (2010) toteamusta siitä, että verkkokiusaamisessa ei ole kysymys vain pienen yhteisön sisällä tapahtuvasta ilmiöstä, vaan se voi muuttua nopeasti julkisen alueen ilmiöksi. Kuten opettajan 4/1 kommentissa ilmeni, jopa sellaiset ihmiset luovat kiusatusta käsityksiä, jotka eivät alunperin tunne kiusattua.

Kiusatun maineeseen ja statukseen vaikuttavan viestinnän toinen keskeinen tekijä on vallan epätasapaino kiusaavan ja kiusatuksi joutuneen oppilaan välillä. Eräs oppilas kuvasi tilannetta, jossa kiusatun on vaikea puolustautua yhteisössä, jossa kiusaajalla on vahvempi suosio:

"Jos joku vaikutusvaltainen tyyppi sanoo, että tää on ihan oikea kuva niin kyl sitä uskotaan mut jos jotain pientä hiirulaista kiusataan ja jos se sanoo, että tää on feikki niin ei sitä kukaan usko.” (Poika 1/2) 
Vallan epätasapaino voi johtua myös siitä, että kiusattu ei tiedä, kuinka monet ihmiset ovat nähneet häntä koskevan juorun tai manipuloidun kuvan. Tämä epätietoisuus aiheuttaa haastateltavien käsitysten mukaan kiusatulle ahdistusta. Toisaalta vallan epätasapainon ajateltiin syntyvän siten, että kiusaaminen tapahtuu kiusatun selän takana. Kiusattu ei välttämättä itse tiedä esimerkiksi kiusaamiseen perustetun ryhmän tai profiilin olemassaolosta tai internetissä julkaistusta kuvasta tai videosta. Pörhölän ja Kinneyn (2010) mukaan kiusattu saattaa huomata kiusaamisen merkit siitä, että muut ihmiset yhtäkkiä muuttavat suhtautumistaan häneen ja alkavat kaikota hänen ympäriltään. Koska kiusattu ei tiedä, mitä on tapahtunut ja kuka tapahtuman takana on, on hänen mahdotonta puolustautua kiusaamista vastaan.

Joskus kiusattu henkilö on tietoinen verkkokiusaamisesta. Hänen on silti vaikea puolustautua sitä vastaan, koska hän ei voi itse poistaa muiden lisäämiä ryhmiä, profiileja, kuvia tai videoita internetistä. Haastateltavien mukaan kiusaajien valtaa lisäsi se, että kiusaamisviestit pysyvät internetissä pitkään. Vaikka kiusanteko olisikin ollut yksittäinen videon julkaisu, sen seurausten voidaan ajatella olevan pitkäkestoista, koska kiusattu kärsii siitä pitkään. Videon voi katsoa lukematon määrä ihmisiä ja se voi pysyä internetissä vuosia. Se voi myös päätyä yksittäisten ihmisten kotikoneille ja siitä myöhemmin taas useille eri internetin sivustoille.

Toiseksi eniten haastatteluissa olivat esillä kiusatun itsearvostukseen ja itsetunnon heikentymiseen liitetyt verkkokiusaamisen muodot. Näille kiusaamisviestinnän muodoille oli tyypillistä kiusatun itsetunnon horjuttaminen ja se, että viestit olivat suoraan osoitettu kiusatulle. Tällaisessa viestinnässä julkisuus ja avoimuus eivät olleet merkityksellisessä asemassa, vaan tavoitteena oli pikemminkin aiheuttaa mielipahaa kiusatulle itselleen. Kuten aiemmassa kiusaamista koskevassa tutkimuskirjallisuudessa on todettu, itsetunnon heikentyminen ja omakuvan muuttuminen kielteisemmäksi on hyvin ominainen seuraus kiusaamisesta (ks. synteesi kiusaamisen vaikutuksista esim. Pörhölä 2009). Tämä tutkimus antaa viitteitä siitä, että verkkokiusaamisesta on eroteltavissa sellainen viestintä, jolla tähän seuraukseen erityisesti pyritään. Myös kiusatun eristäminen mainittiin haastatteluissa melko usein. Tästä voi päätellä, että ryhmän vuorovaikutuksen ulkopuolelle eristäminen, jonka on havaittu olevan tyypillinen kasvokkaisen kiusaamisen muoto (Kouluterveyskysely 2010; Oliver \& Candappa 2008), on myös verkkokiusaamisen muoto.

\section{Verkkokiusaamisen erityispiirteet vaikuttavat käsityksiin ilmiön vakavuudesta}

Opettajat pitivät verkkokiusaamista kasvokkain tapahtuvaa perinteistä kiusaamista julmempana ja vakavampana ilmiönä. Opettajat perustelivat näkemystään erityisesti viestien julkisuudella: teknologiavälitteisesti on mahdollista aiheuttaa 
suurempaa häpeää kiusatulle, koska kiusaamista saattaa todistaa erittäin suuri yleisö. Opettajien mukaan kiusaamisen vakavuutta lisäsi myös valvonnan puute ja se, että kiusattu ei välttämättä tiedä, mitä tehdä ja kenen puoleen kääntyä joutuessaan kiusatuksi internetissä. Oppilaat sen sijaan käsittivät perinteisen, kasvokkain tapahtuvan kiusaamisen verkkokiusaamista vakavammaksi, koska siihen liittyi heidän mielestään riski tulla fyysisesti satutetuksi. Lisäksi oppilaat eivät pitäneet verkkokiusaamista niin vakavana, koska sitä on heidän mukaansa helppo vältellä. Perinteinen kiusaaminen koettiin vaikeammaksi vältellä, koska kiusatuksi joutuneen oppilaan on pakko mennä kouluun.

"Molemmissa on vähän silleen, että netissä on helpompi kiusaaminen väistää jahelpompi kiusata... koulussa on vaikeampi väistää, vaikeampi kiusata." (Tyttö 1/2)

Haastatellut oppilaat ajattelivat, että verkkokiusaamista voi paeta sulkemalla koneen, lopettamalla yhteisöpalvelun käytön tai blokkaamalla kiusaajan viestit. Vakavuutta pohtiessaan he eivät tuoneet esiin sitä mahdollisuutta, että kiusaamisaineistot pysyvät internetissä vaikka tietokone sammutettaisiin. Oppilaat eivät ajatelleet yksittäisten internetin kiusaamisviestien seurauksia kiusatun reaalielämälle, vaan hahmottivat verkkokiusaamisen ennen kaikkea "internetin sisällä" tapahtuvaksi ilmiöksi, joka voidaan torjua vetäytymällä vuorovaikutuksesta.

"No varmaan koulukiusaaminen on vakavampaa. Koska siinä näkee face-to-face tai silleen... et se on kummiskin livenä. Netissä se on silleen, että sä pystyt vaan sammuttamaan koneen, että sillä se vähän niinku loppuu." (Tyttö 2/1)

Oppilaat arvioivat verkkokiusaamisen olevan perinteistä kiusaamista vakavampaa silloin, kun siihen liittyy uhkailua tai kun verkkokiusaaminen laajentuu perinteiseksi kiusaamiseksi. Toisaalta osa haastatelluista oppilaista toi esiin sen, että useimmiten nämä kiusaamisen muodot esiintyvät yhdessä: koulukiusattua kiusataan myös verkossa ja toisinpäin. Oppilaat hahmottivat siis sellaisen verkkokiusaamisen, joka liityy reaalimaailmaan vakavammaksi kuin sellaisen, joka ainoastaan tapahtuu verkossa.

\section{Johtopäätökset}

Verkkokiusaaminen on melko tuore tutkimuskohde. Tutkijoilla ei ole vielä yhteistä näkemystä siitä, onko verkkokiusaaminen oma, erillinen ilmiönsä, vai onko kyseessä yksi kiusaamisen alalaji. Tämän tutkimuksen perusteella verkkokiusaamiseen näyttäisi liittyvän samoja ominaispiirteitä kuin perinteiseen kiusaamiseen. Esimerkiksi voimasuhteiden epätasapaino on läsnä niin perin- 
teisessä kasvokkaisessa kuin verkkokiusaamisessakin, joskin voima määräytyy niissä eri tavoin. Perinteisessä kiusaamisessa epätasapaino voi syntyä esimerkiksi fyysisestä, psyykkisestä tai sosiaalisesta voimasta (Olweus 1992), kun taas verkkokiusaamisen ollessa kyseessä epätasapaino voi tämän tutkimuksen perusteella muodostua kiusaamisviestien nopeasta leviävyydestä ja julkisuudesta tai siitä, että kiusaaminen tapahtuu kiusatun selän takana. Verkkokiusaamisessa on lisäksi nähtävissä kasvokkaisen kiusaamisen kanssa samankaltaisia muotoja, kuten eristämistä, haukkumista ja nimittelyä.

Verkkokiusaaminen kuitenkin vaikuttaa olevan kasvokkaista kiusaamista vahvemmin julkinen ilmiö, joka leviää pienen ryhmän keskuudesta suurille yleisöille helposti. Näin verkkokiusaaminen saattaa vaikuttaa kielteisesti perinteistä kiusaamista voimakkaammin kiusatun maineeseen ja statukseen. Tämä maineen menetys voi olla pysyvämpää kuin kasvokkain tapahtuvassa koulukiusaamistapauksissa, koska viestit voivat levitä kouluyhteisöä laajemmalle ja pysyä internetissä pidempään.

Tulokset antavat viitteitä siitä, että oppilaat ja opettajat näkevät verkkokiusaamisen vakavuuden eri tavoin. Tämä voi olla merkityksellistä verkkokiusaamisen ennaltaehkäisyn ja puuttumisen näkökulmasta. Opettajien mielestä verkkokiusaaminen on vakavaa juuri pitkäaikaisten vaikutusten vuoksi. Tämän vuoksi he katsoivat sen olevan myös kasvokkaista kiusaamista vakavampaa. Oppilailla sen sijaan ajattelumalli "se, mikä ei fyysisesti satuta, ei ole niin vakavaa" oli yleinen. He käsittivät verkkokiusaamisen internetin tai kännykän sisällä tapahtuvaksi kiusaamiseksi, joka tapahtuu tässä hetkessä ja joka loppuu, jos kiusattu vetäytyy teknologiavälitteisestä vuorovaikutuksesta.

Kiusaamisen muotojen tarkastelua tavoitteiden näkökulmasta voidaan pitää tuoreena tapana tutkia verkkokiusaamista. Tässä tutkimuksessa huomio kiinnittyi siihen, mihin viestinnällä mahdollisesti pyritään tai mitä se kenties saa aikaan. Välttämättä kiusaaminen ei aina ole tietoista (Pörhölä, Karhunen \& Rainivaara 2006). Näin ollen jonkun ihmisen maine saattaa ajattelemattomien yksittäisten tekojen vuoksi tärveltyä, vaikkei siihen olisikaan tietoisesti vertaisryhmässä pyritty. Tulevat tutkimukset näyttävät, tarjoaako kiusaamisen muotojen tarkastelu tavoitteiden näkökulmasta uusia avauksia esimerkiksi kiusaamisen vaikutusten tarkastelulle. Mikäli tavoitteiden tarkastelu tavoittaa jotakin keskeistä kiusaamisprosessien vuorovaikutuksesta, on mahdollista, että tätä näkökulmaa voitaisiin soveltaa esimerkiksi kiusaamisen lyhyt- ja pitkäaikaisvaikutusten tutkimukseen. Jos oppilas on esimerkiksi joutunut toistuvasti pitkän ajan kuluessa sellaisen viestinnän kohteeksi, joka erityisesti horjuttaa hänen itsetuntoaan, voivat seuraukset poiketa melkoisesti sellaisesta kiusaamisesta, jolla ensisijaisesti tavoitellaan kiusatun maineen tahraamista vertaisryhmässä. 


\section{Kirjallisuus}

Aarnio, A. \& Multisilta, J. 2012. Facebook ja Youtube - ne on meidän juttu! Kansallinen tutkimus lasten ja nuorten sosiaalisen median ja verkkopalveluiden käytöstä 2011. [online]. Helsingin yliopisto. CICERO learning. [Viitattu 4.10.2012]. Saatavana www-muodossa: <URL:http:// www.cicero.fi/sivut2/documents/LastenjanuortensomeCICERO2012.pdf>

Alasuutari, P. 2007. Laadullinen tutkimus. Tampere: Vastapaino.

Campbell, M. A. 2005. Cyber bullying: An old problem in new guise? Australian Journal of Guidance and Counselling 15 (1), 68-76.

Dehue, F., Bolman, C. \& Völlink, T. 2008. Cyberbullying: Youngsters' experiences and parental perception. CyberPsychology \& Behavior 11 (2), 217-223.

Eskola, J. \& Suoranta, J. 1998. Johdatus laadulliseen tutkimukseen. Tampere: Vastapaino.

EU Kids Online. 2010. Risks and Safety on the internet. [Viitattu 4.10.2012]. Saatavanawww-muodossa: <URL:http://www2.lse.ac.uk/media@lse/ research/EUKidsOnline/Home.aspx>

Hamarus, P. 2006. Koulukiusaaminen ilmiönä. Yläkoululaisten käsityksiä koulukiusaamisesta. Jyväskylä Studies in Education, Psychology and Social Research 288.

Hamarus, P. 2008. Koulukiusaaminen. Huomaa, puutu, ehkäise. Helsinki: Kirjapaja.

Hamarus, P. \& Kaikkonen, P. 2008. School bullying as a creator of pupil peer pressure. Educational Research 50 (4), 333-345.

Hirsjärvi, S. \& Hurme, H. 2001. Tutkimushaastattelu. Teemahaastattelun teoria ja käytäntö. Helsinki: Yliopistopaino.

Hirsjärvi, S., Remes, P. \& Sajavaara, P. 2006. Tutki ja kirjoita. (12. painos) Helsinki: Tammi.

Huhtala, N. 2007. Kiusaamisen uudet pelikentät - peruskoulun 6. luokan oppilaiden kokemuksia ja käsityksiä internet- ja kännykkäkiusaamisesta. Lapin yliopisto. Kasvatustieteen pro gradu -tutkielma.

Karhunen, S. \& Pörhölä, M. 2007. Koulukiusaamisen viestinnälliset piirteet: Havaitsemisen ja tunnistamisen haasteita. [verkkoartikkeli]. Helsinki: Opetushallitus, opettajien verkkopalvelu Edu.fi [viitattu 4.10.2012]. Saatavana www-muodossa: <URL:http://www.edu.fi/ yleissivistava_koulutus/hyvinvointi_koulussa/oppilas_ja_opiskelijahuolto/ erilaiset_ongelma-ja_kriisitilanteet/kiusaaminen_vakivalta_ja hairinta/ koulukiusaamisen viestinnalliset piirteet>

Kouluterveyskysely 2010. Koko maata koskevat kysymyskohtaiset taulukot. Koulukiusaaminen. [Viitattu 4.10.2012]. Saatavana: <URL:http://info. stakes.fi/kouluterveyskysely/FI/tulokset/index.htm>

Kowalski, R. M., Limber, S. P. \& Agatston, P. 2008. Cyberbullying. Oxford: Blackwell.

Li, Q. 2007. New bottle but old wine: A research of cyberbullying in schools. Computers in Human Behavior 23 (4), 1777-1791. 
Lommi, A., Luopa, P., Puusniekka, R., Vilkki, S., Jokela, J. \& Kinnunen, T. 2010. Kouluterveys 2010. Pääkaupunkiseudun raportti. [online]. Terveyden ja Hyvinvoinnin laitos. [Viitattu 4.10.2012]. Saatavilla www-muodossa: <URL: http://www.hel2.fi/Helsinginseutu/liitteet/PKS_kouluterveys_2010. pdf $>$

Macklem, G. L. 2003. Bullying and teasing. Social power in children's groups. New York: Kluwer Academic.

Mustonen, A. \& Peura, J. 2007. Netin kuvagalleriat nuorten elämässä. Nettikyselyn tuloksia 2007. Tulosten vertailua 2006 ja 2007. [online]. Mannerheimin Lastensuojeluliitto. [Viitattu 4.10.2012]. Saatavilla wwwmuodossa: <URL: http://www.mll.fi/@Bin/11904188/Netin+kuvagalleriat+ nuorten+el $\% \mathrm{C} 3 \% \mathrm{~A} 4 \mathrm{~m} \% \mathrm{C} 3 \% \mathrm{~A} 4 \mathrm{ss} \% \mathrm{C} 3 \% \mathrm{~A} 4 . \mathrm{pdf}>$

Nieminen, H. \& Pörhölä, M. 2011. Lasten ja nuorten verkkokiusaamisen tutkimushaasteita. Teoksessa M. Valo, A. Sivunen \& V. Laaksonen (toim.) Prologi. Puheviestinnän vuosikirja 2011. Jyväskylä: Prologos, 74-85.

Oliver, C. \& Candappa, M. 2007. Bullying and the politics of 'telling'. Oxford Review of Education 33 (1), 71-86.

Olweus, D. 1992. Kiusaaminen koulussa. Suomentaja Maija Mäkelä. Helsinki: Otava.

Oksanen, A. \& Näre, S. 2006. Lapset pelissä. Virtuaaliviidakon ansat. Jyväskylä: Minerva.

Patchin, J. W. \& Hinduja, S. 2006. Bullies move beyond the schoolyard: A Preliminary look at cyberbullying. Youth Violence and Juvenile Justice 4 (2), 148-165.

Pörhölä, M. 2009. Psychosocial well-being of victimized students. In T. A. Kinney \& M. Pörhölä (eds) Anti and pro-social communication. Theories, methods, and applications. New York: Peter Lang, 83-93.

Pörhölä, M., Karhunen, S. \& Rainivaara, S. (2006). Bullying at school and in the workplace. A challenge for communication research. In C. Beck (Ed.) Communication Yearbook 30. Mahwah: Erlbaum, 249-301.

Pörhölä, M. \& Kinney, T. A. 2010. Bullying: Contexts, consequences, and control. Barcelona: Editorial Aresta.

Rainivaara, S. \& Karhunen, S. 2006. Näkökulmia koulun ja työpaikan kiusaamissuhteisiin. Teoksessa T.-R. Välikoski, E. Kostiainen, E. Kyllönen \& L. Mikkola (toim.) Prologi. Puheviestinnän vuosikirja 2006. Jyväskylä: Prologos, 8-40.

Salmivalli, C. 2003. Koulukiusaamiseen puuttuminen. Kohti tehokkaita toimintamalleja. Jyväskylä: PS-Kustannus.

Salmivalli, C. \& Pöyhönen, V. 2012. Cyberbullying in Finland. In Q. Li, D. Cross \& P. Smith (eds) Cyberbullying in the Global Playground: Research from International Perspectives, 57-72.

Slonje, R. \& Smith, P. K. 2008. Cyberbullying: Another type of bullying. Scandinavian Journal of Psychology 49 (2), 147-154. 
Smith, P. K., Mahdavi, J., Carvalho, M. \& Tippet, N. 2006. An investigation into cyberbullying, its forms, awareness and impact and the relationship between age and gender in cyberbullying. [online]. [Viitattu 4.10.2012]. Saatavilla www-muodossa: <URL:https://www.education.gov.uk/ publications/eOrderingDownload/RBX03-06.pdf>

Smith, P. K., Mahdavi, J., Carvalho, M., Fisher, S., Russell, S. \& Tippet, N. 2008. Cyberbullying: Its nature and impact in secondary school pupils. Journal of Childs Psychology and Psychiatry 49 (4), 376-385.

Sourander, A., Brunstein Klomek, A., Ikonen, M., Lindroos, J., Luntamo, T., Koskelainen, M., Ritskari, T. \& Helenius, H. 2010. Psychosocial risk factors associated with cyberbullying among adolescent. Arch Gen Psychiatry 67 (7), 720-728.

Tuomi, J. \& Sarajärvi, A. 2002. Laadullinen tutkimus ja sisällönanalyysi. Helsinki: Tammi.

Vandebosch, H. \& Van Cleemput, K. 2008. Defining cyberbullying: A qualitative research into the perceptions of youngsters. Cyberspychology 11 (4), 499-503.

Varjas, K., Talley, J., Mayers, J. Parris, L. \& Cutts, H. 2010. High school students' perceptions of motivations for cyberbullying: An exploratory study. Western Journal of Emergency Medicine 11(3), 269-273.

Willard, N. 2005. Educators guide to cyberbullying and cyberthreats. [online]. [Viitattu 4.10.2012]. Saatavana www-muodossa: <URL: http://csriu.org/ cyberbully/docs/cbcteducator.pdf>

Ybarra, M. L. \& Mitchell. K. J. 2004. Youth engaging online harassment: Associations with caregiver-child relationships, Internet use, and personal characteristics. Journal of Adolescence 27 (3), 319-336. 